\title{
Endothelin-1 (ET-1), N-terminal fragment of pro-atrial natriuretic peptide (NTpro-ANP), and tumour necrosis factor alpha (TNF- $\alpha$ ) in children with primary hypertension and hypertension of renal origin
}

\author{
Endotelina-1 (ET-1), N-końcowy fragment przedsionkowego peptydu \\ natriuretycznego (NTpro-ANP), czynnik martwicy nowotworu alfa (TNF- $\alpha$ ) \\ w nadciśnieniu tętniczym pierwotnym oraz nadciśnieniu nerkopochodnym \\ w wieku rozwojowym
}

\author{
Beata Banaszak' ${ }^{1}$ Elżbieta Świętochowska ${ }^{2}$ Paweł Banaszak ${ }^{3}$, Katarzyna Ziora $^{1}$ \\ ${ }^{1}$ Department of Paediatrics, School of Medicine with the Division of Dentistry in Zabrze, Medical University of Silesia in Katowice, \\ Zabrze, Poland \\ ${ }^{2}$ Department of Medical and Molecular Biology, School of Medicine with the Division of Dentistry in Zabrze, Medical University \\ of Silesia in Katowice, Zabrze, Poland \\ ${ }^{3}$ Department of Congenital Heart Diseases and Pediatric Cardiology, Silesian Centre for Heart Diseases, Zabrze, Poland
}

\begin{abstract}
Introduction: Hypertension is regarded as a condition of mild inflammation and endothelial imbalance. The aim of the study was to evaluate serum concentrations of biomarkers of inflammation and endothelial function: tumour necrosis factor alpha (TNF- $\alpha$ ), endothelin-1 (ET-1), and N-terminal fragment of pro-atrial natriuretic peptide (NTpro-ANP) in hypertensive and normotensive children.

Material and methods: We studied 63 children aged $13.56 \pm 3.73$ years, divided into two groups: a group with primary hypertension $(n=50)$ and a group with renal hypertension $(n=13)$. The control group consisted of 34 normotensive children aged $12.76 \pm 3.96$ years. Biomarkers were measured with ELISA tests.

Results: ET-1 levels were significantly higher in primary hypertension $(9.93 \pm 1.73 \mathrm{pg} / \mathrm{ml})$ and renal hypertension $(10.77 \pm 1.50 \mathrm{pg} / \mathrm{ml})$ in comparison to controls $(4.03 \pm 0.97 \mathrm{pg} / \mathrm{ml}),(\mathrm{p}<0.001, \mathrm{p}<0.001$, respectively). NT-pro ANP concentrations in primary hypertension $(71.03 \pm 10.02 \mathrm{pg} / \mathrm{ml})$, and renal hypertension $(84.78 \pm 6.44 \mathrm{pg} / \mathrm{ml})$ were significantly higher than in the control group $(29.62 \pm 5.56$ $\mathrm{pg} / \mathrm{ml})(\mathrm{p}<0.001, \mathrm{p}<0.001$, respectively). TNF- $\alpha$ concentrations in primary hypertension $(8.36 \pm 1.60 \mathrm{pg} / \mathrm{ml})$ and renal hypertension $(7.35 \pm 0.93 \mathrm{pg} / \mathrm{ml})$ significantly exceeded concentrations in controls $(4.49 \pm 0.93 \mathrm{pg} / \mathrm{ml}),(\mathrm{p}<0.001, \mathrm{p}<0.001$, respectively). ET-1 and NT-pro ANP concentrations in renal hypertension significantly exceeded those in primary hypertension $(\mathrm{p}=0.049, \mathrm{p}<0.001$, respectively) while TNF- $\alpha$ levels in renal hypertension were significantly lower than in primary hypertension $(p=0.046)$.

Conclusions: The results of our study show that ET-1, NT-pro ANP, and TNF- $\alpha$ concentrations are increased in hypertension in children. Our investigation indicates significant importance of inflammation and endothelial involvement in hypertension in youth. (Endokrynol Pol 2019; 70 (1): 37-42)
\end{abstract}

Key words: hypertension; children; endothelin 1; atrial natriuretic peptide; tumour necrosis factor alpha

\section{Streszczenie}

Wstęp: W rozwoju nadciśnienia tętniczego istotną rolę przypisuje się procesom zapalnym oraz zaburzeniom równowagi śródbłonka naczyń. Celem pracy była ocena stężenia markerów stanu zapalnego oraz aktywności śródbłonka: czynnika martwicy nowotworu alfa (TNF- $\alpha$ ), endoteliny-1 (ET-1) oraz N-końcowego fragmentu przedsionkowego peptydu natriuretycznego (NTpro-ANP) u dzieci z nadciśnieniem tętniczym.

Materiał i metody: W badaniu uczestniczyło 63 dzieci z nadciśnieniem tętniczym w wieku 13,56 $\pm 3,73$ roku, w tym 50 dzieci z rozpoznaniem pierwotnego nadciśnienia tętniczego oraz 13 dzieci z rozpoznaniem nadciśnienia nerkopochodnego. Grupę kontrolną stanowiło 34 dzieci w wieku $12,76 \pm 3,96$ roku z prawidłowym ciśnieniem tętniczym. Stężenia TNF- $\alpha$, ET-1, NTpro-ANP wykonywano metodą ELISA. Wyniki: Uzyskano istotnie wyższe stężenia ET-1 w grupie dzieci z pierwotnym nadciśnieniem tętniczym $(9,93 \pm 1,73 \mathrm{pg} / \mathrm{ml}) \mathrm{oraz}$ nerkopochodnym nadciśnieniem $(10,77 \pm 1,50 \mathrm{pg} / \mathrm{ml})$ w porównaniu z grupą kontrolną $(4,03 \pm 0,97 \mathrm{pg} / \mathrm{ml})(\mathrm{p}<0,001, \mathrm{p}<0,001)$. Podobną zależność obserwowano dla NT-pro ANP, uzyskując istotnie wyższe stężenie u badanych z pierwotnym nadciśnieniem tętniczym $(71,03 \pm 10,02 \mathrm{pg} / \mathrm{ml})$ oraz nerkopochodnym nadciśnieniem $(84,78 \pm 6,44 \mathrm{pg} / \mathrm{ml})$ w porównaniu z dziećmi z prawidłowym ciśnieniem tętniczym $(29,62 \pm 5,56 \mathrm{pg} / \mathrm{ml})(\mathrm{p}<0,001, \mathrm{p}<0,001)$. Stężenia TNF- $\alpha$ były istotnie wyższe wśród badanych z pierwotnym nadciśnieniem tętniczym $(8,36 \pm 1,60 \mathrm{pg} / \mathrm{ml})$ oraz nerkopochodnym nadciśnieniem $(7,35 \pm 0,93 \mathrm{pg} / \mathrm{ml})$ niż u badanych z grupy kontrolnej $(4,49 \pm 0,93$ $\mathrm{pg} / \mathrm{ml})(\mathrm{p}<0,001, \mathrm{p}<0,001)$. U pacjentów z nadciśnieniem nerkopochodnym stężenia ET-1 oraz NT-pro ANP istotnie przewyższały przy tym stężenia analogicznych markerów uzyskane u pacjentów z pierwotnym nadciśnieniem tętniczym $(p=0,049$, $p<0,001)$, podczas gdy stężenie TNF- $\alpha \mathrm{w}$ grupie dzieci z nadciśnieniem nerkopochodnym było istotnie niższe niż u dzieci z pierwotnym nadciśnieniem tętniczym $(\mathrm{p}=0,046)$. 
Wnioski: Istotnie wyższe stężenia ET-1, NT-pro ANP oraz TNF- $\alpha$ u dzieci w nadciśnieniu tętniczym pierwotnym oraz nerkopochodnym wskazują na znaczenie zaburzeń równowagi śródbłonkowej w rozwoju choroby nadciśnieniowej w wieku rozwojowym. (Endokrynol Pol 2019; 70 (1): 38-42)

Kluczowe słowa: nadciśnienie tętnicze; dzieci; endotelina 1; czynnik martwicy nowotworu alfa; przedsionkowy peptyd natriuretyczny

\section{Introduction}

There is growing concern about elevated blood pressure in children and adolescents. Until recently it was thought that secondary forms of hypertension dominate in youth, but recent reports show the increasing prevalence of primary hypertension among paediatric patients [1]. Despite constant scientific progress, it still seems to be a challenge to reveal the mechanisms underlying hypertension. Hypertension has been considered to be a low-grade inflammatory condition characterised by the presence of various cytokines [2]. Tumour necrosis factor alpha (TNF- $\alpha$ ) is a constituent of proinflammatory cytokines reported to be engaged in alterations of endothelial function in hypertension $[3,4]$. TNF- , by its influence on diminished nitric oxide bioavailability, acts itself as a vasoconstrictor, but it also initiates endothelin-1 (ET-1) release [5]. ET-1, a product of endothelial cells, shows positive paracrine impact on vascular tone [6]. ET-1 seems to be a marker of endothelial engagement in hypertension. Unfortunately, scientific data on ET-1 concentrations in hypertensive patients are not consistent [7]. Endothelial hyperreactivity in hypertension, leading to vasoconstriction, can be potentially balanced by mechanisms based on the promotion of natriuresis and vasorelaxation. Atrial natriuretic peptide (ANP) is a factor that stimulates both processes. The literature shows that plasma concentrations of ANP can be increased in hypertension [8]. Current studies concentrate on markers of endothelial function in hypertensive adults; investigations depicting children are scarce. Because in the paediatric population the increasing phenomenon of primary hypertension is incontestable, there is still a vast proportion of patients with hypertension of renal origin induced by global or segmental renal blood flow impairment. Aiming to get better view in the process of inflammation and endothelial contribution in hypertension of the young, we compared serum concentrations of TNF- $\alpha$, ET- 1 , and $\mathrm{N}$-terminal fragment of pro-atrial natriuretic peptide (NTpro-ANP) in children with primary hypertension, renal hypertension, and normotensive controls.

\section{Material and methods}

\section{Study sample}

The study was performed among children referred to the Division of Paediatric Nephrology in Zabrze due to a history of elevated blood pressure from August 2016 and July 2017, who underwent evaluation according to the recommendations of the European Society of Hypertension [10]. Office blood pressure (BP) was measured with the validated oscillometric method with use of IntelliVue MX700 device and referred to normative data for age, sex, and height provided by the US Task Force for children under three years old and by OLAF (study on the population of Polish children) for children in the age range 3-18 years [11,12]. BP classification was based on 2016 European Society of Hypertension Guidelines on High Blood Pressure in Children and Adolescents: normal BP, systolic blood pressure (SBP), and diastolic blood pressure (DBP) $<90^{\text {th }}$ percentile for age, sex, and height in a group aged 1-15 years and $\mathrm{BP}<130 / 85 \mathrm{~mm} \mathrm{Hg}$ in a group aged 16 years and older; hypertension: $3 \mathrm{BP}$ measurements (on admission and two consecutive days) $\geq 95^{\text {th }}$ percentile for age, sex, and height in a group aged 1-15 years and SBP and/or DBP $\geq 140 / 90 \mathrm{mmHg}$ in a group aged 16 years and older [10]. Patients with hypertension aged five years and more and/or with height of minimum 120 $\mathrm{cm}$ underwent ambulatory blood pressure monitoring (ABPM) with use of a SunTech device regarding the $95^{\text {th }}$ percentile for SBP according to sex, age, and height and 25\% SBP load as thresholds for ambulatory hypertension [13, 14]. Children with "white coat hypertension" were not enrolled in the study.

Patients with office BP hypertension and ambulatory hypertension underwent diagnostic evaluation recommended by the European Society of Hypertension aimed at revealing secondary forms of hypertension [10].

Laboratory tests including plasma creatinine, urea, uric acid, electrolytes, fasting glucose, cholesterol, triglycerides, plasma renin activity, aldosterone, thyroid function tests, urinalysis and culture, quantification of albuminuria, urine metanephrine as well as echocardiography with the assessment of the aortic arch, renal ultrasonography, and renal Doppler ultrasonography were performed in all patients. Moreover, in obese children plasma cortisol was measured. Patients with the suspicion of vascular, hormonal, or monogenic forms of hypertension underwent further diagnostic evaluation and were not enrolled in the study. Subjects with abnormalities in urinalysis, blood tests (creatinine, urea, uric acid, electrolytes), and/or renal ultrasonography needed additional procedures like renoscintigraphy and/or cystourethrography to establish a diagnosis; they were classified as patients with renal hypertension. Subjects 
with no abnormalities, apart from disturbances typical for metabolic syndrome, were classified as patients with primary hypertension.

The study comprised 63 hypertensive subjects aged $13.56 \pm 3.73$, range $2.0-18.0$ years, with a diagnosis of primary hypertension (50 patients, aged $14.09 \pm 3.77$, range 2.0-17.9 years) and renal hypertension (13 patients, aged 13.6 \pm 2.68 , range 9.9-18.0 years: six with renal hypodysplasia, four with ectopic kidney, and three with reflux nephropathy). Younger children (under 10 years of age) made up $14.3 \%$ of the study group (7 out of 50 children (14\%) with primary hypertension, 2 out of 13 children (15.4\%) with renal hypertension). None of the participants was administered hypertensive drugs prior to the entry to the study. The control group consisted of 34 subjects, aged $12.76 \pm 3.96$, range 6.25-17.75 years with normal office BP according to 2016 European Society of Hypertension guidelines measured with the validated oscillometric method with use of an IntelliVue MX700 device. Younger children (under 10 years of age) made up $17.6 \%$ of the control group (6 out of 34 children). The study protocol was approved by the Silesian Medical University Bioethical Committee and all the participants' parents as well as participants aged 16 years and older provided written, informed consent. Participants underwent routine medical history, measurements of height and weight, and laboratory assessment.

\section{Medical history and clinical evaluation}

All those surveyed had a negative medical history for chronic diseases and chronic medication as well as for any acute infectious disease or major trauma within two weeks prior to the enrolment. Subjects' parents completed an interview aimed at obtaining information about family history of hypertension, and/or diabetes, and/or cardiovascular events, and perinatal history of the participants regarding prematurity and birth weight. Body mass index (BMI) was calculated as weight (kilograms) divided by the square of the height (metres). BMI was referred to the sex-specific BMI-for-age growth charts provided by the World Health Organisation for children under five years old and by OLAF for children at the age of 5-18 years [15]. BMI was presented as a percentile value.

\section{Laboratory assessment}

After overnight fasting, blood samples obtained by venepuncture were collected. Measurements of serum concentrations of c-reactive protein (CRP), glucose, creatinine, uric acid, sodium, potassium, bicarbonate, total cholesterol, high-density lipoprotein (HDL) cholesterol, low-density lipoprotein (LDL) cholesterol, and triglycerides were performed. The estimated glo- merular filtration rate (GFR) was calculated according to the Schwartz formula [16].

Blood samples for the measurement of serum concentrations of ET-1, NT-pro ANP, and TNF- $\alpha$ were centrifuged and serum specimens were stored at $-70^{\circ} \mathrm{C}$ until analysis. Concentrations of ET-1 were measured using an ELISA kit (Cloud-Clone Corp., Houston, TX, USA) with an inter-assay variation below $12 \%$ and intra-assay variation below $10 \%$. Serum concentrations of NT-pro ANP were measured using an ELISA kit (Cloud-Clone Corp., Houston, TX, USA) with an inter-assay variation below $11 \%$ and intra-assay variation below $9 \%$. Serum concentrations of TNF $\alpha$ were measured using an ELISA kit (TNF $\alpha$ Hu 950.090.096, Diaclone SAS, France) with an inter-assay variation below $7.8 \%$ and intra-assay variation below $5.4 \%$.

\section{Statistical analysis}

Database management and statistical analysis were performed with the STATISTICA data analysis software system (version 12, StatSoft, Inc.). Comparisons between the group with primary hypertension, the group with normal blood pressure, and the group with renal hypertension were performed for qualitative and quantitative variables. Proportions were compared using the $\chi^{2}$ test. Quantitative variables were analysed for normal distribution by the Shapiro-Wilk test. On account of distribution drifting away from normal, U Mann-Whitney test was performed to compare quantitative variables. P-values $<0.05$ were considered statistically significant.

\section{Results}

Baseline and biochemical characteristics of study samples are shown in Tables I-III. Significantly higher BMI percentile values in patients with primary hypertension when compared to patients with renal hypertension and normal blood pressure were observed ( $p=0.004$ and $p<0.001$, respectively). There was a significant increase in serum CRP $(p=0.005)$, triglycerides $(p=0.026)$, and uric acid $(p<0.001)$ and a decrease in HDL levels $(p=0.034)$ in primary hypertensive subjects compared to normotensive controls. In the comparison between groups with primary and renal hypertension, significantly higher uric acid ( $p=0.018)$ and lower HDL $(p<0.001)$ serum concentrations were observed in primary hypertensive participants. Serum concentrations of ET-1, NT-pro ANP, TNF- in study samples are shown in Table IV. ET-1 levels were significantly higher in children with primary hypertension $(9.93 \pm 1.73 \mathrm{pg} / \mathrm{ml})$ and renal hypertension $(10.77 \pm 1.50 \mathrm{pg} / \mathrm{ml})$ in comparison to controls $(4.03 \pm 0.97 \mathrm{pg} / \mathrm{ml}),(\mathrm{p}<0.001, \mathrm{p}<0.001$, respec- 
Table I. Baseline characteristics of the study sample for quantitative variables

Tabela I. Charakterystyka badanych grup pod względem wybranych parametrów jakościowych

\begin{tabular}{|c|c|c|c|c|c|c|c|c|c|}
\hline & \multicolumn{2}{|c|}{$\begin{array}{l}\text { Primary hypertension } \\
\qquad(\mathrm{n}=50)\end{array}$} & \multicolumn{2}{|c|}{$\begin{array}{l}\text { Normal blood pressure } \\
\qquad(\mathrm{n}=34)\end{array}$} & \multicolumn{2}{|c|}{$\begin{array}{l}\text { Renal hypertension } \\
\quad(\mathrm{n}=13)\end{array}$} & \multirow{2}{*}{\begin{tabular}{|l} 
p value \\
1 vs. 2
\end{tabular}} & \multirow{2}{*}{\begin{tabular}{|l} 
p value \\
1 vs. 3
\end{tabular}} & \multirow{2}{*}{$\begin{array}{l}\text { p value } \\
2 \text { vs. } 3\end{array}$} \\
\hline & Mean & SD & Mean & SD & Mean & SD & & & \\
\hline $\begin{array}{l}\text { Age [years] } \\
\text { (min.-max.) }\end{array}$ & $\begin{array}{c}14.09 \\
(2.0-17.9)\end{array}$ & 3.77 & $\begin{array}{c}12.76 \\
(6.25-17.75)\end{array}$ & 3.96 & $\begin{array}{c}13.60 \\
(9.9-18.0)\end{array}$ & 2.68 & 0.127 & 0.312 & 0.712 \\
\hline BMI percentile & 89.16 & 17.33 & 72.85 & 26.25 & 73.00 & 24.53 & 0.004 & $<0.001$ & 0.625 \\
\hline Birth weight [g] & 3328.40 & 612.72 & 3490.29 & 635.23 & 3005.39 & 708.49 & 0.407 & 0.124 & 0.072 \\
\hline
\end{tabular}

BMI — body mass index; SD — standard deviation

Table II. Baseline characteristics of study samples for qualitative variables

Tabela II. Charakterystyka badanych grup pod względem wybranych parametrów ilościowych

\begin{tabular}{|c|c|c|c|c|c|c|c|c|c|}
\hline & \multicolumn{2}{|c|}{$\begin{array}{l}\text { Primary hypertension } \\
\qquad(\mathrm{n}=50)\end{array}$} & \multicolumn{2}{|c|}{$\begin{array}{l}\text { Normal blood pressure } \\
\qquad(\mathrm{n}=34)\end{array}$} & \multicolumn{2}{|c|}{$\begin{array}{l}\text { Renal hypertension } \\
\qquad(\mathrm{n}=13)\end{array}$} & \multirow{2}{*}{$\begin{array}{l}\text { p value } \\
1 \text { vs. } 2 \\
\end{array}$} & \multirow{2}{*}{\begin{tabular}{|l} 
p value \\
1 vs. 3 \\
\end{tabular}} & \multirow{2}{*}{$\begin{array}{l}\text { p value } \\
2 \text { vs. } 3\end{array}$} \\
\hline & $\mathrm{n}$ & $\%$ & $\mathrm{n}$ & $\%$ & $n$ & $\%$ & & & \\
\hline $\begin{array}{l}\text { Positive family history for } \\
\text { hypertension and/or diabetes } \\
\text { and/or cardiovascular events }\end{array}$ & 31 & $62.0 \%$ & 5 & $14.7 \%$ & 4 & $30.8 \%$ & $<0.001$ & 0.088 & 0.402 \\
\hline Prematurity & 5 & $10.0 \%$ & 1 & $2.9 \%$ & 1 & $7.7 \%$ & 0.423 & 0.781 & 0.932 \\
\hline
\end{tabular}

Table III. Biochemical characteristics of study samples

Tabela III. Charakterystyka badanych grup pod względem wybranych parametrów biochemicznych

\begin{tabular}{|c|c|c|c|c|c|c|c|c|c|}
\hline & \multicolumn{2}{|c|}{$\begin{array}{l}\text { Primary hypertension } \\
\qquad(\mathrm{n}=\mathbf{5 0})\end{array}$} & \multicolumn{2}{|c|}{$\begin{array}{l}\text { Normal blood pressure } \\
\qquad(\mathrm{n}=34)\end{array}$} & \multicolumn{2}{|c|}{$\begin{array}{l}\text { Renal hypertension } \\
\quad(n=13)\end{array}$} & \multirow{2}{*}{$\begin{array}{l}\text { p value } \\
1 \text { vs. } 2 \\
\end{array}$} & \multirow{2}{*}{$\begin{array}{l}\text { p value } \\
1 \text { vs. } 3 \\
\end{array}$} & \multirow{2}{*}{$\begin{array}{l}\text { p value } \\
2 \text { vs. } 3 \\
\end{array}$} \\
\hline & Mean & SD & Mean & SD & Mean & SD & & & \\
\hline $\mathrm{Na}[\mathrm{mmol} / \mathrm{l}]$ & 140.20 & 1.73 & 140.32 & 1.79 & 140.85 & 1.99 & 0.565 & 0.244 & 0.412 \\
\hline $\mathrm{K}$ [mmol/l] & 4.50 & 0.29 & 4.45 & 0.27 & 4.30 & 0.26 & 0.243 & 0.034 & 0.168 \\
\hline $\mathrm{HCO}_{3}(\mathrm{mmol} / \mathrm{l})$ & 24.00 & 2.34 & 23.15 & 1.83 & 24.21 & 1.75 & 0.113 & 0.832 & 0.101 \\
\hline GFR [ml/min/1,7] & 97.81 & 20.06 & 102.32 & 18.30 & 85.09 & 14.35 & 0.177 & 0.052 & 0.005 \\
\hline Uric acid [umol/l] & 360.56 & 72.21 & 284.94 & 72.32 & 311.54 & 49.77 & $<0.001$ & 0.018 & 0.096 \\
\hline Glucose [mg/dl] & 92.25 & 6.01 & 91.67 & 5.19 & 91.20 & 6.25 & 0.362 & 0.288 & 0.552 \\
\hline Cholesterol [mmol/l] & 4.05 & 0.62 & 4.15 & 0.66 & 4.32 & 0.78 & 0.529 & 0.270 & 0.643 \\
\hline LDL [mmol/l] & 2.31 & 0.60 & 2.32 & 0.65 & 2.28 & 0.74 & 0.799 & 0.604 & 0.576 \\
\hline $\mathrm{HDL}[\mathrm{mmol} / \mathrm{l}]$ & 1.16 & 0.26 & 1.28 & 0.29 & 1.60 & 0.58 & 0.034 & $<0.001$ & 0.032 \\
\hline CRP (mg/l) & 1.38 & 1.33 & 0.87 & 1.04 & 0.91 & 1.12 & 0.005 & 0.070 & 0.972 \\
\hline Triglycerides [mmol/l] & 1.28 & 0.58 & 1.08 & 0.83 & 1.14 & 0.52 & 0.026 & 0.455 & 0.385 \\
\hline
\end{tabular}

$\mathrm{N}$ - sodium; $\mathrm{K}$ - potassium; $\mathrm{HCO}_{3}$ — hydrogencarbonate; GFR — glomerular filtration rate; LDL — density lipoprotein; HDL — high density lipoprotein;

CRP - C-reactive protein; SD — standard deviation

tively). NT-pro ANP concentrations in patients with primary hypertension $(71.03 \pm 10.02 \mathrm{pg} / \mathrm{ml})$ and renal hypertension $(84.78 \pm 6.44 \mathrm{pg} / \mathrm{ml})$ were significantly higher than in a control group $(29.62 \pm 5.56 \mathrm{pg} / \mathrm{ml})$, ( $\mathrm{p}<0.001, \mathrm{p}<0.001$, respectively). TNF- $\alpha$ concentrations in subjects with primary hypertension $(8.36 \pm 1.60 \mathrm{pg} / \mathrm{ml})$ and renal hypertension $(7.35 \pm 0.93$ $\mathrm{pg} / \mathrm{ml}$ ) significantly exceeded concentrations in con- trols $(4.49 \pm 0.93 \mathrm{pg} / \mathrm{ml}),(\mathrm{p}<0.001, \mathrm{p}<0.001$, respectively). ET-1 and NT-pro ANP concentrations in children with renal hypertension significantly exceeded analogous concentrations in a group with primary hypertension ( $\mathrm{p}=0.049, \mathrm{p}<0.001$ respectively) while TNF- $\alpha$ levels in patients with renal hypertension were significantly lower than in a group with primary hypertension $(\mathrm{p}=0.046)$. 
Table IV. ET-1, NT-pro ANP, and TNF- $\alpha$ concentrations in the study samples Tabela IV. Stężenie ET-1, NT-pro ANP, TNF- $\alpha$ w badanych grupach

\begin{tabular}{|c|c|c|c|c|c|c|c|c|c|}
\hline & \multicolumn{2}{|c|}{$\begin{array}{l}\text { Primary hypertension } \\
\qquad(\mathrm{n}=\mathbf{5 0})\end{array}$} & \multicolumn{2}{|c|}{$\begin{array}{l}\text { Normal blood pressure } \\
\qquad(\mathrm{n}=34)\end{array}$} & \multicolumn{2}{|c|}{$\begin{array}{l}\text { Renal hypertension } \\
\quad(\mathrm{n}=13)\end{array}$} & \multirow{2}{*}{$\begin{array}{l}\text { p value } \\
1 \text { vs. } 2\end{array}$} & \multirow{2}{*}{\begin{tabular}{|l} 
p value \\
1 vs. 3
\end{tabular}} & \multirow{2}{*}{\begin{tabular}{|l} 
p value \\
2 vs. 3
\end{tabular}} \\
\hline & Mean & SD & Mean & SD & Mean & SD & & & \\
\hline ET-1 [pg/ml] & 9.93 & 1.73 & 4.03 & 0.97 & 10.77 & 1.50 & $<0.001$ & 0.049 & $<0.001$ \\
\hline NT-pro ANP [pg/ml] & 71.03 & 10.02 & 29.62 & 5.56 & 84.78 & 6.44 & $<0.001$ & $<0.001$ & $<0.001$ \\
\hline TNF- $\alpha$ [pg/ml] & 8.36 & 1.60 & 4.49 & 0.93 & 7.35 & 0.95 & $<0.001$ & 0.046 & $<0.001$ \\
\hline
\end{tabular}

ET-1 — endothelin-1; NTpro-ANP — N-terminal fragment of pro-atrial natriuretic peptide; TNF- $\alpha$ — tumour necrosis factor alpha; SD — standard deviation

\section{Discussion}

We investigated biomarkers of inflammation and endothelial function in conditions of hypertension and normotension in children and adolescents. The vast majority of participants of the study were children at pubertal age, which reflects the typical age distribution for youngsters with newly diagnosed hypertension. We identified a statistical link between elevated levels of TNF- $\alpha$, ET-1, NT pro-ANP, and primary hypertension as well as hypertension of renal origin.

TNF- $\alpha$, a pro-inflammatory cytokine that is a product of macrophages, lymphocytes, and endothelial cells, by its influence on nitric oxide synthase mRNA, leads to the decrease in bioavailability of nitric oxide, which causes vasoconstriction $[3,4]$. The results of our study demonstrate significantly higher concentrations of TNF- $\alpha$ in hypertensive participants than in normotensive ones, which indicates the role of inflammation in primary hypertension and renal hypertension. Significantly higher levels of TNF- $\alpha$ in participants with primary hypertension than in participants with renal hypertension may point to the causative function of inflammation in primary hypertension while in renal hypertension low-grade inflammation may be only a secondary phenomenon. TNF- $\alpha$, among other pro-inflammatory cytokines, regulates $\mathrm{CRP}$ production [17]. Significantly higher concentrations of CRP in subjects with primary hypertension in comparison to the control group tend to confirm the leading position of inflammation in essential hypertension. The theory of inflammatory pathogenesis of hypertension has been postulated in the literature. Wang et al. proved CRP to be one of the predictors of pending hypertension [18]. Bautista et al. showed in their study a significant link between interleukin- 6 and TNF- $\alpha$ and high blood pressure, while Głowińska et al. indicated an association between TNF- $\alpha$ and hypertension and obesity [19, 20]. The connection between high blood pressure and obesity has been well defined [21]. Under circumstances of obesity, adipocytes behave like immune cells, able to release proinflammatory adipokines and cytokines including TNF- $\alpha$ and CRP [22]. The results of our survey show that children with primary hypertension had significantly higher BMI percentile than children with renal hypertension and normal blood pressure, which may serve as an explanation for higher TNFand CRP concentrations. The survey of Zhen et al. shows that uric acid inhibits nitric oxide expression and induces TNF- $\alpha$ expression, which suggests that uric acid induces endothelial inflammation [23]. On the other hand, according to Riwanto et al., HDL directly stimulates endothelial cell production of nitric oxide as well as endothelial repair processes, which causes HDL to be an anti-inflammatory factor [24]. In our project a group with primary hypertension was characterised by significantly higher concentrations of uric acid and significantly lower concentrations of HDL. The results discussed above acknowledge the position of inflammation in pathogenesis of hypertension. Endothelium possesses mechanisms able to maintain balance between dilating and constricting factors. ET-1, produced by vascular endothelium, acting in a paracrine fashion on vascular smooth muscles cells, is one of the best-known vasoconstrictors [25]. Although scientific data seem not to be consistent, there are studies indicating a link between elevated ET-1 levels and hypertension [7, 26]. In our study we observed significantly higher plasma concentrations of ET- 1 in hypertensive participants than in normotensive controls. Interestingly, ET-1 concentrations were statistically higher in children with renal hypertension than in children with primary hypertension. ET-1 synthesis and release can be stimulated either by vasoactive hormones and shear stress or by free radicals and pro-inflammatory cytokines [5]. Probably in hypertension of renal origin the renin-angiotensin system plays a major role in ET-1 stimulation while in primary hypertension ET-1 seems to be dependent on low-grade inflammation. There is research indicating a role of ET- 1 in the formation of reactive oxygen species and pro-inflammatory cytokines, which can potentially explain the pathogenesis of inflammation in hypertension of renal origin [27]. ET-1 stimulates ANP synthesis. ANP, being the main opponent of ET-1 and 
the renin-angiotensin system, promotes vasorelaxation, diuresis, and natriuresis [28]. In our study we noticed significantly higher concentrations of NTpro-ANP in hypertensive participants than in normotensive ones. Interestingly, NTpro-ANP levels were higher in children with renal hypertension when compared to children with primary hypertension. If we consider conclusions derived from the research of Mussalo et al. pointing to higher plasma levels of NT-pro ANP in patients with renovascular hypertension than in patients with essential hypertension, we can postulate that clinical conditions connected with impaired renal blood flow evoke more expressive ANP response [9].

\section{Conclusions}

The results of our study show that ET-1, NT-pro ANP, and TNF- $\alpha$ concentrations are increased in hypertension in children. While in primary hypertension TNF- $\alpha$ is much more significant, in renal hypertension ET-1 and NT-pro ANP dominate. Our investigation indicates the significant importance of inflammation and endothelial involvement in hypertension in youths.

\section{Funding}

\section{SUM, KNW-1-097/N/6/K.}

\section{References}

1. Falkner B. Hypertension in children and adolescents: epidemiology and natural history. Pediatr Nephrol. 2010; 25(7): 1219-1224, doi: 10.1007/s00467-009-1200-3, indexed in Pubmed: 19421783.

2. Bautista LE. Inflammation, endothelial dysfunction, and the risk of high blood pressure: epidemiologic and biological evidence. J Hum Hypertens. 2003; 17(4): 223-230, doi: 10.1038/sj.jhh.1001537, indexed in Pubmed: 12692566

3. Mehaffey E, Majid DSA. Tumor necrosis factor-, kidney function, and hypertension. Am J Physiol Renal Physiol. 2017; 313(4): F1005-F1008, doi: 10.1152/ajprenal.00535.2016, indexed in Pubmed: 28724611

4. Ramseyer VD, Garvin JL. Tumor necrosis factor- : regulation of renal function and blood pressure. Am J Physiol Renal Physiol. 2013; 304(10): F1231-F1242, doi: 10.1152/ajprenal.00557.2012, indexed in Pubmed: 23515717.

5. Virdis A, Schiffrin EL. Vascular inflammation: a role in vascular disease in hypertension? Curr Opin Nephrol Hypertens. 2003; 12(2): 181-187, doi: 10.1097/01.mnh.0000058797.51455.ad, indexed in Pubmed: 12589179.

6. Meyers KEC, Sethna C. Endothelin antagonists in hypertension and kidney disease. Pediatr Nephrol. 2013; 28(5): 711-720, doi: 10.1007/s00467-012-2316-4, indexed in Pubmed: 23070275.

7. Kostov K, Blazhev A, Atanasova M. Serum Concentrations of Endothelin-1 and Matrix Metalloproteinases-2, -9 in Pre-Hypertensive and Hypertensive Patients with Type 2 Diabetes. Int J Mol Sci. 2016; 17(8), doi: 10.3390/ijms17081182, indexed in Pubmed: 27490532

8. Suzuki T, Yamazaki T, Yazaki Y. The role of the natriuretic peptides in the cardiovascular system. Cardiovasc Res. 2001; 51(3): 489-494, indexed in Pubmed: 11476739.

9. Mussalo H, Vanninen E, Ikäheimo R, et al. NT-proANP and BNP in renovascular and in severe and mild essential hypertension. Kidney Blood Press Res. 2003; 26(1): 34-41., doi: 10.1159/000069763, indexed in Pubmed: 12697975.

10. Lurbe E, Agabiti-Rosei E, Cruickshank JK. 2016 European Society of Hypertension guidelines for the management of high blood pressure in children and adolescents. J Hypertens. 2016; 34(10): 1887-1920, doi: 10.1097/HJH.0000000000001039, indexed in Pubmed: 27467768.

11. National High Blood Pressure Education Program Working Group on High Blood Pressure in Children and Adolescents. The fourth report on the diagnosis, evaluation, and treatment of high blood pressure in children and adolescents. Pediatrics. 2004; 114(2 Suppl): 555-576, indexed in Pubmed: 15286277.

12. Kułaga Z, Litwin M, Grajda A, et al. Rozkłady wartości ciśnienia krwi $\mathrm{w}$ populacji referencyjnej dzieci i młodzieży w wieku szkolnym [Blood Pressure Trends in Children and Adolescents: Predictors of Blood Pressure Elevation in Children and Adolescents]. Standardy Medyczne Pediatria. 2010; 7(5/6): 853-864.

13. Urbina E, Alpert B, Flynn J, et al. American Heart Association Atherosclerosis, Hypertension, and Obesity in Youth Committee. Ambulatory blood pressure monitoring in children and adolescents: recommendations for standard assessment: a scientific statement from the American Heart Association Atherosclerosis, Hypertension, and Obesity in Youth Committee of the council on cardiovascular disease in the young and the council for high blood pressure research. Hypertension. 2008; 52(3): 433-451, doi: 10.1161/HYPERTENSIONAHA.108.190329, indexed in Pubmed: 18678786.

14. Wühl E, Witte K, Soergel M. Distribution of 24-h ambulatory blood pressure in children: normalized reference values and role of body dimensions. J Hypertens. 2002; 20(10): 1995-2007, indexed in Pubmed: 12359978

15. Kułaga Z, Litwin M, Tkaczyk M. Polish 2010 growth references for school-aged children and adolescents. Eur J Pediatr. 2011; 170(5): 599-609, doi: 10.1007/s00431-010-1329-x, indexed in Pubmed: 20972688.

16. Schwartz GJ, Muñoz A, Schneider MF. New equations to estimate GFR in children with CKD. J Am Soc Nephrol. 2009; 20(3): 629-637, doi: 10.1681/ASN.2008030287, indexed in Pubmed: 19158356

17. Baumann H, Gauldie J. The acute phase response. Immunol Today. 1994; 15(2): 74-80, doi: 10.1016/0167-5699(94)90137-6, indexed in Pubmed: 7512342 .

18. Wang TJ, Gona P, Larson MG. Multiple biomarkers and the risk of incident hypertension. Hypertension. 2007; 49(3): 432-438, doi: 10.1161/01. HYP.0000256956.61872.aa, indexed in Pubmed: 17242302.

19. Bautista LE, Vera LM, Arenas IA, et al. Independent association between inflammatory markers (C-reactive protein, interleukin-6, and TNF-alpha) and essential hypertension. J Hum Hypertens. 2005; 19(2): 149-154, doi: 10.1038/sj.jhh.1001785, indexed in Pubmed: 15361891.

20. Głowińska B, Urban M. Wybrane cytokiny (IL-6, IL-8, IL-10, MCP-1, TNF-alpha) u dzieci i młodzieży obarczonych tradycyjnymi czynnikami ryzyka miażdżycy: otyłościa, nadciśnieniem, cukrzyca [Selected cytokines (Il-6, Il-8, Il-10, MCP-1, TNF-alpha) in children and adolescents with atherosclerosis risk factors: obesity, hypertension, diabetes]. Wiad Lek. 2003; 56(3-4): 109-116, indexed in Pubmed: 12923954.

21. Paradis G, Lambert M, O'Loughlin J. Blood pressure and adiposity in children and adolescents. Circulation. 2004; 110(13): 1832-1838, doi: 10.1161/01.CIR.0000143100.31752.B7, indexed in Pubmed: 15381642.

22. Sarzani R, Salvi F, Dessì-Fulgheri P. Renin-angiotensin system, natriuretic peptides, obesity, metabolic syndrome, and hypertension: an integrated view in humans. J Hypertens. 2008; 26(5): 831-843, doi: 10.1097/HJH.0b013e3282f624a0, indexed in Pubmed: 18398321.

23. Zhen $\mathrm{H}$, Gui $\mathrm{F}$. The role of hyperuricemia on vascular endothelium dysfunction. Biomed Rep. 2017; 7(4): 325-330, doi: 10.3892/br.2017.966, indexed in Pubmed: 28928970.

24. Riwanto M, Landmesser U. High density lipoproteins and endothelial functions: mechanistic insights and alterations in cardiovascular disease. J Lipid Res. 2013; 54(12): 3227-3243, doi: 10.1194/jlr.R037762, indexed in Pubmed: 23873269

25. Kohan DE, Rossi NF, Inscho EW. Regulation of blood pressure and salt homeostasis by endothelin. Physiol Rev. 2011; 91(1): 1-77, doi: 10.1152/physrev.00060.2009, indexed in Pubmed: 21248162.

26. Dhaun N, Goddard J, Kohan DE, et al. Role of endothelin-1 in clinical hypertension: 20 years on. Hypertension. 2008; 52(3): 452-459, doi: 10.1161/HYPERTENSIONAHA.108.117366, indexed in Pubmed: 18678788

27. Dong F, Zhang X, Wold LE. Endothelin-1 enhances oxidative stress, cell proliferation and reduces apoptosis in human umbilical vein endothelial cells: role of ETB receptor, NADPH oxidase and caveolin-1. Br J Pharmacol. 2005; 145(3): 323-333, doi: 10.1038/sj.bjp.0706193, indexed in Pubmed: 15765100.

28. Demerath T, Staffel J, Schreiber A. Natriuretic peptides buffer renin-dependent hypertension. Am J Physiol Renal Physiol. 2014; 306(12): F1489-F1498, doi: 10.1152/ajprenal.00668.2013, indexed in Pubmed: 24717731. 